\title{
The Quality of Diagnosis by IR Thermography as a Function of Thermal Stimulation in Chosen Medical Applications
}

\author{
by A. Trafarski*, L. Różanski*, A. Straburzynska - Lupa**, P. Korman** \\ ${ }^{*}$ Poznan University of Technology, Poznan, Poland \\ ${ }^{* * P o z n a n ́ ~ U n i v e r s i t y ~ S c h o o l ~ o f ~ P h y s i c a l ~ E d u c a t i o n, ~, ~ P o z n a n, ~ P o l a n d ~}$
}

\begin{abstract}
The working of many physical procedures used in medical science is connected to changes in the temperature of tissue. A research has been carried out into the possibility of using the thermographic technique in evaluating the effectiveness of local cryotherapy procedure (local cryostimulation) in patients with rheumatoid arthritis. The aim of the research was to determine the degree of thermal stimulation intensity during the local cryotherapy procedure and duration of response of the organism to the applied stimulation. The research was based on comparison of temperature distribution on the surface of the hand prior to, immediately after, and at certain intervals after the procedure of local blast of liquid nitrogen vapours or cool air on the hand. All people taking part in the study suffered from rheumatoid arthritis, accompanying illnesses occurring in some of them. Similar procedures were used to study the accompanying reactions connected with application of anti-cellulite cream. In both cases similar reactions of the organism to the applied stimulation were observed. The study allowed to optimize thermal stimulation procedures used in rheumatology and cosmetology.
\end{abstract}

\section{Introduction}

Solving the problems of modern science and engineering is connected with the need to create image converters whose spectral sensitivity region would encompass possibly wide wavelength intervals of electromagnetic and elastic waves. Among the most important converters are thermographs, which have been found useful in, inter alia, object detection (the military, police, fire-brigade, security, lifesaving, transport), scientific research (physics, biology, geology,...), supporting industry (monitoring buildings and machines, nondestructive testing, control of technological processes, electronic engineering, power industry, building industry, automotive industry, shipbuilding industry,...), medical science (evaluating the effectiveness of medicines and procedures, medical diagnostics) $[3,4]$.

\section{The bases of the systems operation}

Thermography is a technique of recording radiant energy emitted in infrared range. The basis of operation of thermographic systems is connected with detection and recording of infrared radiation (IR) emitted by the examined object, and corresponding conversion of this radiation into the radiation in the visible region of electromagnetic wave spectrum. This way, black and white or colourful images (thermograms, thermal images) of the invisible infrared radiation are obtained. IR radiation is a carrier of information about the temperature of an object because its power (more precisely, its radiance) depends on temperature. What is created are thermograms on which the luminance or colour of visible light correspond to particular values of the radiant flux emitted by the examined body, which allows to picture the distribution of temperature. In medical science, thermographic systems that work in 2-5, 8-9 or 8-12 $\mu \mathrm{m}$ ranges are used [2, 3, 4]. In radiation measurements of temperature with thermographic systems three types of errors can occur: errors of method, errors of calibration and errors of electronic measurement system [4]. In medical applications errors of method can be omitted in

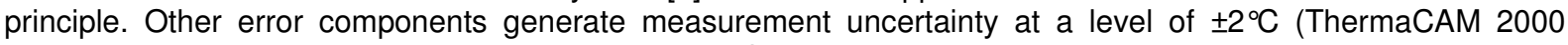
produced by FLIR with temperature resolution of $0,1^{\circ} \mathrm{C}$ ). Research done using differential method with the use of an external referential temperature model allows to reduce the uncertainty of thermographic measurement carried out under laboratory conditions to app. $0,5^{\circ} \mathrm{C}[7,8]$.

\section{Methodology of tests}

Measurements were performed with special attention given to ensure the replicability of climatic conditions of all tests. The room was air-conditioned, the temperature was maintained between $20-22^{\circ} \mathrm{C}$, with humidity in the range of $45-50 \%$. All external sources of heat (radiators, lightning, etc.) were separated; there was no draught. The acclimation of patient lasted for 15 minutes and took place in a room with similar conditions. People waiting for the recording of another thermal image also stayed in identical conditions. While moving from the cryotherapy room to the diagnostic room the examined person did not touch any objects (did not open the door on their own etc.). In the case of examining the response of the patient to the procedure of local cryostimulation, ThermaCAM SC 2000 thermograph camera was placed perpendicular to the horizontal surface on which the patients placed their hands on an insulating mat specially prepared beforehand. In the case of cosmetological tests, the camera was placed perpendicular to the chosen body part at a distance of app. $1 \mathrm{~m}$. Before taking the tests connected with cryostimulation, the patients had not smoked, nor drunk coffee, alcohol, or any other stimulants, had not applied any ointment, body lotion or other cosmetics (washed and degreased skin); they had avoided any 
physical exertion and had not undergone any other physical procedures. For the sake of local cryostimulation, 15 minutes before the procedure and in between each measurement the patients were not allowed to clench their fists, chafe their hands, keep their hands in their pockets, etc. For the veracity and replicability of the tests it was necessary to meet the standards concerning the equipment (it must be calibrated) and software (it must allow for proper recording, filing of data and its full analysis) [3, 4]. The testing procedure involved recording of thermographs directly prior to the procedure; next, the patients underwent local cryostimulation (blast of liquid nitrogen vapours or cooled air) and immediately after the procedure another thermograph recording was make. Subsequent recordings were made 5, 15, 30, 45, 60, 120 and 180 minutes after the procedure. The procedure of local cryotherapy on the hand consisting in the application of the blast of liquid nitrogen vapours lasted 2 minutes and was performed with circular movements on both sides of the hand at the distance of app. 10-15 cm. The procedure of blast of cool air $\left(\approx-35^{\circ} \mathrm{C}\right)$ with the maximal airflow of $100 \mathrm{l} / \mathrm{min}$, however, lasted 3 minutes and was performed with circular movements on both sides of the hand at the distance of app. $2-3 \mathrm{~cm}$. In both cases the procedure was applied to one hand only. In the case of cosmetological tests, for each of the examined patients, thermographs of chosen parts of both legs from the front and back as well as the left and right side were recorded. Thermographic images were recorded prior to and 2 and 4 weeks after the carried out procedure (Fig. 1). On their basis, histograms of surface temperature distribution were made. Here it was essential to indicate the differences between 'healthy' and 'ill' areas. In the case of 'healthy' areas, the histogram encompasses a small range of temperatures, while in the case of areas 'attacked' by cellulite, the range is much wider and depends on the level of illness development. The research was carried out with the consent of the relevant medical boards in the Rheumatological Rehabilitation Laboratory of Poznań University School of Physical Education (AWF) and the Dr Irena Eris Research Laboratory in Warsaw under close medical supervision.
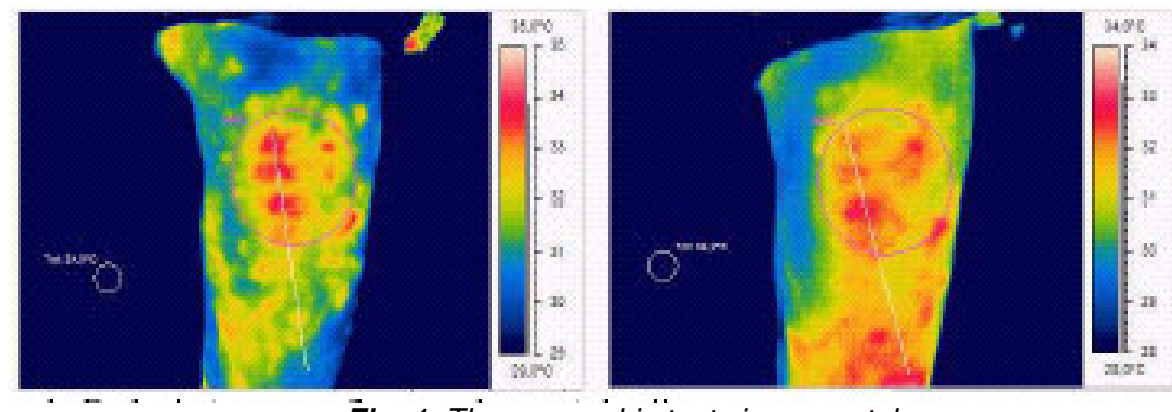

Fig. 1. Thermographic tests in cosmetology

\section{Results of the research and results analysis}

Computer analysis of the obtained thermal images was carried out with the use of ThermaCAM Reporter 2000 and ThermaCAM Research 2000 programs. It was assumed that skin emissivity is 0,98. The charts related to the procedures of local cryotherapy for the group cooled with liquid nitrate vapours and the group cooled with $\mathrm{cool}$ air that illustrate the course of temperature changes during the thermographic procedure (Fig. 2) were prepared on the basis of results of mean temperatures from the tested area. For each patient, the reference level was assumed to be their body temperature prior to the procedure. Only the temperature rises caused by the carried out procedure were measured. From the charts presented in Fig. 2 it follows that in stimulation with liquid nitrogen vapours response of the organism is more acute.
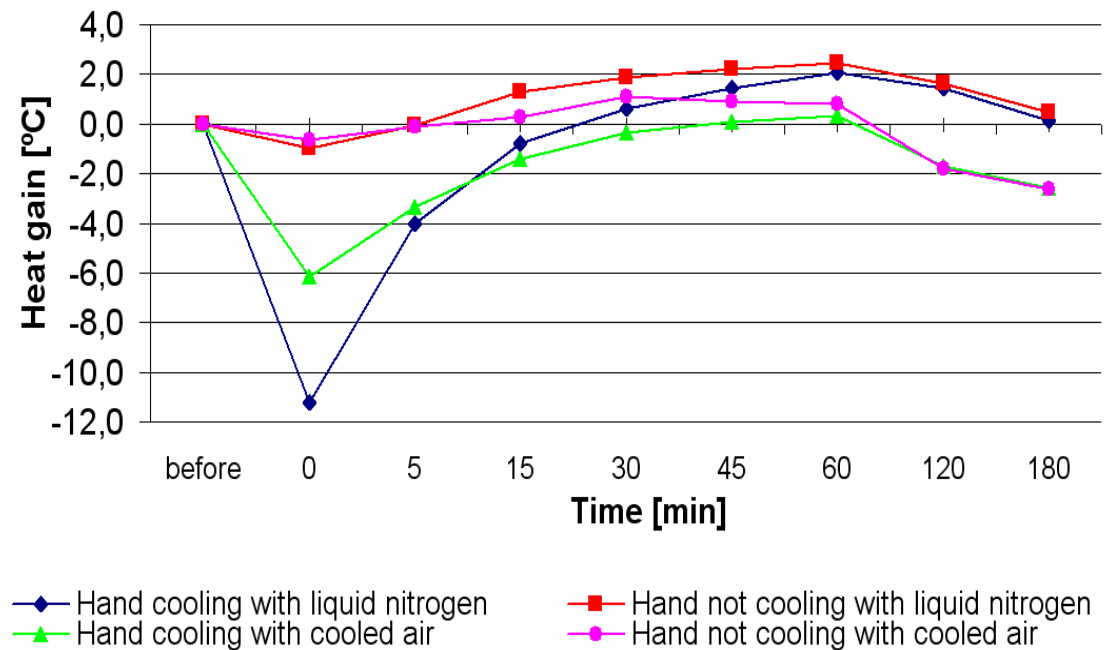

Fig. 2. Response of the organism to thermal stimulation with liquid nitrogen vapours and cool air 
The temperature of cooled hands (hands subject to the procedure) dropped by $11,2^{\circ} \mathrm{C}$ on average; a drop in the temperature of the hand not subject to the procedure was also observed - a drop by app. $1^{\circ} \mathrm{C}$ on average. In the case of cooling with cool air, however, the drop in the temperature of the cooled hand was app. $7,3^{\circ} \mathrm{C}$, and of the hands not subject to cooling - app. $0,7^{\circ} \mathrm{C}$. The temperature rise during the hyperemia of hands (a defense reaction of the organism) was also higher for liquid nitrate vapours: $2,1^{\circ} \mathrm{C}$ in cooled hands and $2,5^{\circ} \mathrm{C}$ in hands not subject to cooling. In the case of cooling with cool air, the temperatures were $0,7^{\circ} \mathrm{C}$ and $1,4^{\circ} \mathrm{C}$ respectively. The above quoted values of temperature changes are mean values calculated for the examined group of patients. It was discovered that response of the organism to stimulation with liquid nitrate vapours lasts over 2 hours, while in the case of cool air it amounts to app.90 minutes. Fig. 3 illustrates the comparison of temperature rises for the patients ill with rheumatoid arthritis (RA) and patients ill with both RA and arterial hypertension (AH) that were subject to cooling with liquid nitrate vapours. Fig. 4 presents similar charts, yet they refer to the procedure of cooling done with cool air.

In the case of stimulation with liquid nitrate vapours no significant changes in temperature rise were observed (between groups RA and $R A+A H$ ), while for the stimulus produced by cool air a smaller drop in temperature due to stimulation and a faster temperature rise during the process of arriving at the initial state were observed. The duration of response of the organism to stimulation did not change in the case of using liquid nitrate vapours, while in the case of cool air a peculiar drop in temperature was observed after 60 minutes. It turns out, however, that temperatures of the hands do not drop below the mean body temperature in the case of patients with RA and $\mathrm{AH}$. This is illustrated by charts (Fig. 4). Histograms in Fig. 5 and 6 illustrate the distribution of temperature connected with discovering the foci of cellulite. They allow to estimate the extent and progression of the aberration in microcirculation which leads to changes in the distribution of temperature on the skin. The study of blood flow in capillaries revealed that its mean flow in subcutaneous tissue and the skin attacked by cellulite is $35 \%$ lower than in healthy tissue [1]. It is reflected in uneven skin temperature distribution in such areas, and the areas of reduced blood flow are characterized by lower surface temperature. The obtained results of thermographic tests allowed for an objective estimation of the level of progression of cellulite prior to applying the chosen treatment, during the treatment and after its termination.

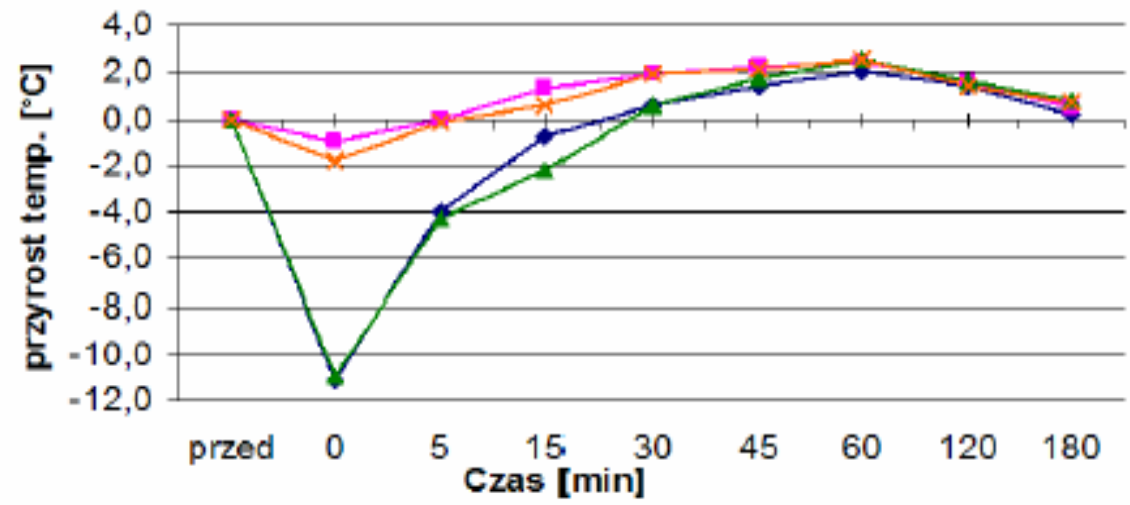

Ręka schłodzona RZS

- Reka schiodzona RZS + NT

- - Ręka nie schłodzona RZS

$\rightarrow$ Ręa nie schiodzona RZS +NT

Fig. 3. Response of the organism to thermal stimulation with liquid nitrogen vapours.
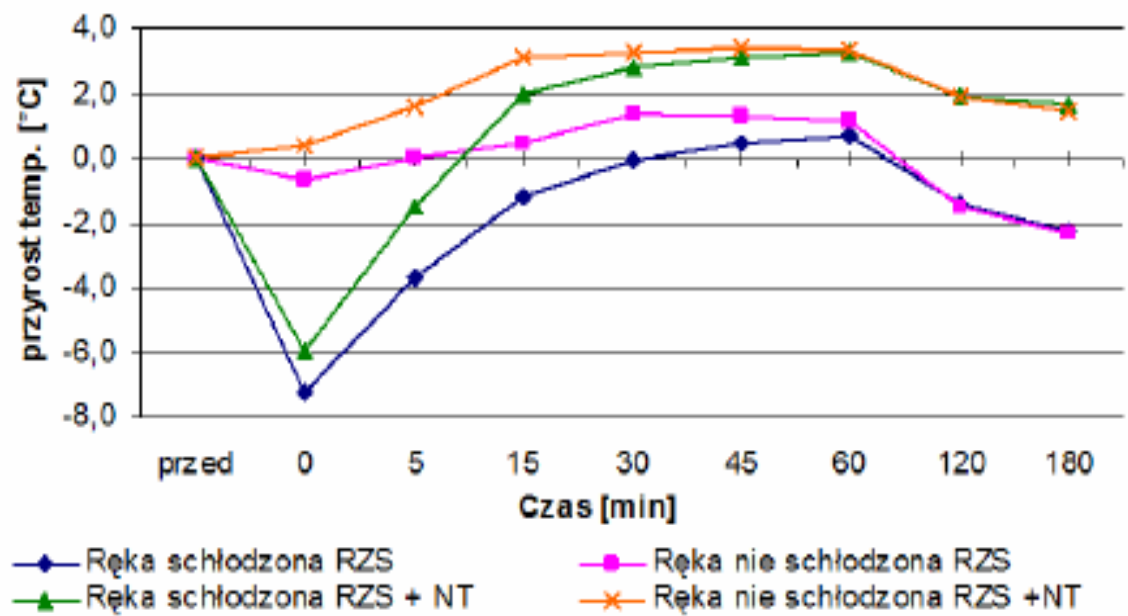

Fig. 4. Response of the organism to thermal stimulation with cool air. 

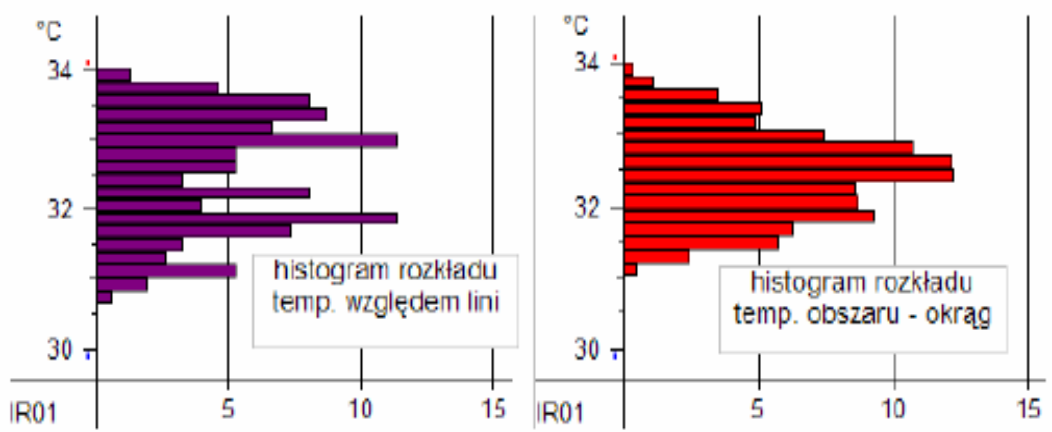

Fig. 5. Cosmetological tests prior to the treatment.
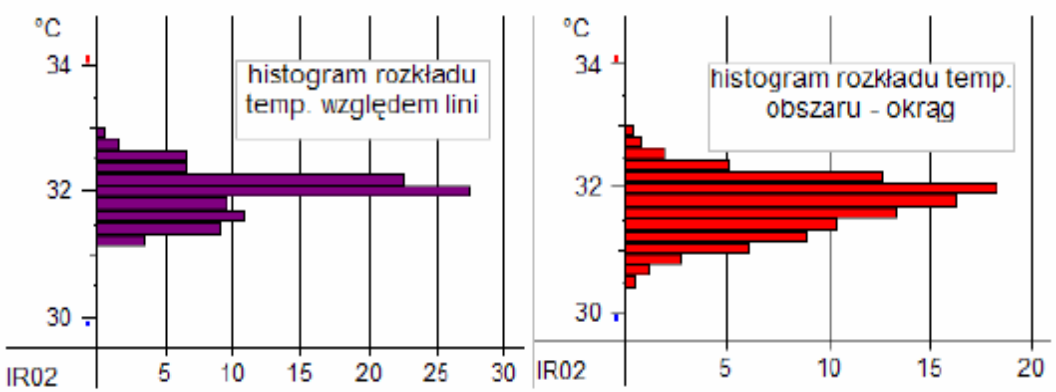

Fig. 6. Cosmetological tests after the treatment.

\section{Conclusions}

The carried out research demonstrated that thermography is a measurement technique useful in analysing thermal reaction of the organism connected with local cryostimulation, in discovering foci of cellulite, and monitoring and evaluating the progress of treatment. It was revealed that the stimulus produced by liquid nitrate vapours is a much stronger thermal stimulation for the patient than the stimulus produced by cool air. Duration of response to the stimulation in patients ill only with RA was longer in the case of stimulation with liquid nitrate vapours. A faster and bigger temperature rise, as well as longer duration of organism response to stimulation with cool air was observed in patients ill with RA and $\mathrm{AH}$. Further research should be carried out which would be directed at discovering the proper diversification and adequate optimization of testing procedures concerning cellulite and cryotherapy procedures applied in various morbid cases accompanying RA, as well as in various stages of progression of RA.

\section{REFERENCES}

[1] A. B. Rossi, and A. L. Vergnanini. Cellulite, praca przeglądowa (1), Dermatologia Estetyczna, 6(17) (2001) 259-267.

[2] A. Hanua, M Stucker, T. Gambichler, A. Orlikov, K. Hoffman, P. Altmejer and M. Freitag. Noninvasive diagnosis of skin functions, Hautarzt, 12(54) (2003) 1211-1223.

[3] A. Nowakowski. Postępy termografii - aplikacje medyczne, Wydawnictwo Gdańskie (2001).

[4] H. Madura. Pomiary termowizyjne w praktyce, Agenda Wydawnicza PAK (2004).

[5] D. Leśińska-Filipowicz and R. Żaba. Badania termograficzne i jego zastosowania w dermatologii - podstawy teoretyczne, Dermatologia Estetyczna, 2 (2000) 224-233.

[6] H. Podbielska, J. Kobel, I. Hołowacz, P. Hurnik, W. Mielczarek and J. Zdziarski. Analiza obrazów termowizyjnych w wybranych zastosowaniach medycznych i biomedycznych. Biocybernetyka i Inżynieria Biomedyczna 2000, tom 8, Obrazowanie Biomedyczne, Akademicka Oficyna Wydawnicza EXIT (2003), 517-532.

[7] S. Poloszyk and L. Różański. Kształtowanie właściwości metrologicznych systemów diagnostyki termograficznej. Pomiary Automatyka Kontrola, 4, (2002), 36-39.

[8] C. Vincent, M. Szubert, R. Dębowska, K. Bazela, I. Eris, L. Różański, M. Stroiński, Z. Jaskólska and A. Duszyńska. Zastosowanie termografii w diagnostyce cellulite. Dermatologia Kosmetyczna, 2(43) (2006) 8589.

[9] W. Minkina. Pomiary termowizyjne, przyrządy i metody. Wydawnictwo Politechniki Częstochowskiej (2004).

[10] B. Więcek and S. Zwolenik. Termografia jako nieinwazyjna metoda diagnostyki w medycynie. Możliwości i osiagnięcia. III Światowe Targi Liderów Nowoczesnej Technologii MEDYCYNA'99, Łódź. Annales Academiae Medicae Lodzensis (40) (2000). 